\title{
Vacuum Appropriation Strategies between Patio and Pavilion Archetypes Hybridization in Two Classical Masters Works of Modern Architecture
}

\author{
By Simone Solinas ${ }^{*}$
}

Patio and pavilion, understood as archetypes, may appear as opposing principles in the construction of space. However, we can see through the analysis of some of the proposed cases that the overlap of these principles takes place very frequently, because they both arise from the need to delimit the vacuum by giving to it the character of space. The vacuum is not space, although space may be empty. The vacuum exists without us, whereas space does not. The architect, in designing enclosed space, encapsulates a portion of the vacuum, indistinct and formless, understood as Nature. This is a fragment of Paradise that everyone has right to possess, by binding an idea to the image of the patio and pavilion. From their combined use, there are several cases in which these elements take shape in architectural projects. In some projects, one principle dominates the other, but it is evident that there are a large variety of mixed proposals between the two extremes. The two principles do not exclude one another and can coexist together in a complementary way by appearing in the same project. The two figures as archetypes are taken as the main reference points of different poles that seem to be conflicting and irreconcilable ideas, but that instead build together the complexity of architecture. Full $\mid$ empty, outside $\mid$ inside, empty space | full-space, stereotomic | tectonic, vertical | horizontal, centrifugal | centripetal, works together to build space. Using this theoretical and practical approach, we analyse two "classic" works of modern architecture: the Pavilion in Barcelona by Mies and Ville Savoye by Le Corbusier, which both utilize pavilions and patios. The Pompeian house, physically known by LC in his travels and by Mies through its relationship with classicism, constitutes a common point from which the architecture of these masters branches off and reveals an unexpected hybrid synthesis.

\section{Introduction}

This document aims to explain and use some of the void appropriation strategies to think about the compositional similarities that exist between two apparently opposed "classic works", the Mies van der Rohe Pavilion in Barcelona and the Villa Savoye by Le Corbusier in Poissy both built in 1929. This comparison is especially fruitful if you observe the two buildings through a prism using the archetypes of the patio and pavilion as active tools

\footnotetext{
* PhD Candidate, University of Cagliari, Italy.
} 
of analysis, proposing to see the German Pavilion of Barcelona as a pavilion inside a patio, and the Villa Savoye in Poissy as a patio inside a pavilion. ${ }^{1}$

The two figures of patio and pavilion are taken as the main reference points of different poles that seem to be conflicting and irreconcilable ideas, but that instead are building together the complexity of architecture. Full | empty, outside | inside, void-space | full-space, stereotomic | tectonic, vertical | horizontal, centrifugal | centripetal, explosive | implosive, democrat | absolutist, are some of the treated binomials that work together to build this idea. It is therefore argued that both works, as well as many others within the vast panorama of architecture, can be read through the use of these two ideas and in particular by their constant hybridization. Both works of the Swiss master and the German master emphasize these two archetypes and their fusion. In both cases, it is possible to reconstruct a possible story in which the Pompeii house, another synthesis or hybrid between patio and pavilion and between atrium and peristyle, is a reliable and conceptual model for both projects.

\section{The Space}

It is useful for the proposed objectives to suggest a shortly theoretical conception of space, its relation to the void, and how this materializes. The appropriation of the vacuum is an architectural design strategy that aims to enclose a formless void portion. That vacuum finds its most immediate representation in nature and, placed in relation to the full, reaches a balance in the final built system.

The thesis is based on the paradoxical affirmation that the full is not to be understood as the opposite of the void, or that black, for example, is the opposite of white, but that each one must be understood as a material, an entity with its own autonomy. ${ }^{2}$ In the architectural field, the idea of defining the vacuum as an immaterial material always available as material matter seems to be suggestive. The matter with which space is built is therefore a synthesis of two elementary components that we define as full volume units and empty volume units. This idea is based on the hypothesis that full-space and void-space, both understood as materials, are the fundamental components in the construction of space. The vacuum-space is a space component that is associated with the full-space and defines its formal configuration similarly to the ideas, for example, of Eisenman in his first theoretical writings. ${ }^{3}$ These configurations tend towards the definition and achievement of enclosed space.

Man-architect, in designing the enclosed space, encapsulates a portion of the indistinct and formless vacuum, understood as Nature. This is a fragment

1. Richard Padovan, "El pabellón y el patio. Problemas culturales y espaciales de la arquitectura De Stijl," in Espacio fluido versus espacio sistematico (ed.) Ricardo Guash (Barcelona: ETSAV Ediciones UPC, 1955): 18.

2. Giovanni Caradente, Chillida Hierros de temblor II (Bilbao: Bilbokp Arte Ederren, 2015), 7.

3. Peter Eisenman, The formal basis of Modern Architecture (Zurich: Lars Muller Publishers, 2006). 
of Paradise that everyone has "right to possess" as LC describes in his letters to his parents posted from Ema. ${ }^{4}$ Ideas thus bind to the images of the patio and pavilion.

Therefore, it is necessary to constantly keep in mind a binomial, which we indicate as $\mathrm{A} \mid \mathrm{B}$, that keeps together situations in a kind of suspension, appearing to be contrary to the common opinion of oppositions, such as full and void, white and black, science and art, theory and practice, the past and the future, or the classic and the modern, proposing instead a more complex vision that instead of acting by exclusion uses inclusion.

The built space of a work can only be seen as the unattainable summation of several full spaces and empty spaces. Therefore, we can only reconstruct and propose a momentary image that fixes at a given moment a possible point of view of this space. Such images are to be seen as intermediate situations between poles whose opposition is not dichotomous and substantial but bipolar and tensile. The terms (A and B) are neither removed nor compound in units, but rather maintained in an immobile coexistence loaded with tensions: neither A nor B. ${ }^{5}$ At this point, the position and the use of the special idea of patio (A) and pavilion (B) are clear as components of a binomial in which the first term is associated with the idea of the sedentariness bound to the cave, and the second with the idea of wander and therefore of the hut. It is almost impossible not to connect to the patio the image of the Pantheon, despite its hemispherical coverage, and at the idea of the hut the image of the Parthenon (Figure 1).
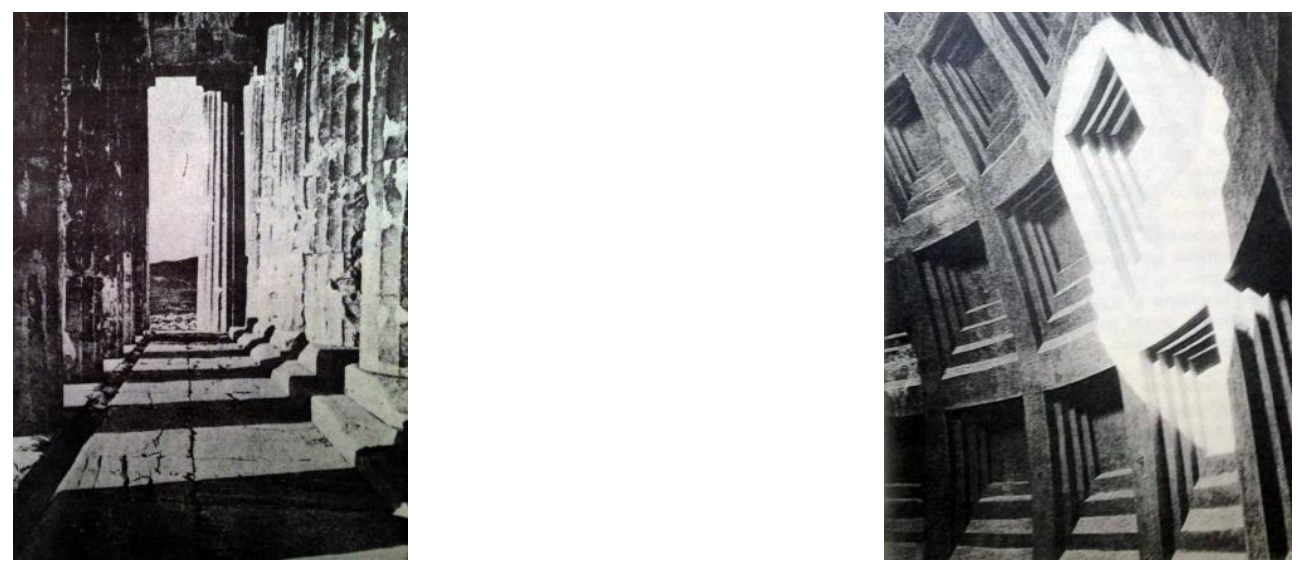

Figure 1. a) Parthenon b) Pantheon

Source: Vers une architecture. Le Corbusier; El Vacio. F. Espuelas.

We can even extrapolate the same idea from the two referenced buildings to more complex spaces like the Acropolis in Athens on one side and the Roman Forum in Rome on the other, as Collin Rowe and Fred Koetter propose in their texts ${ }^{6}$ debating the complex aspect of what is figure and what is background, what is "full" and what is "empty". Well-known examples are

4. Charles Janneret, Carta ai Genitori (Library of Chaux-de-Fonds, 1907).

5. Giorgio Agamben, Ninfe (Torino: Bollati Boringhieri, 2007), 34.

6. Collin Rowe and Fred Koetter, Collage City (Milano: Il Saggiatore, 1981), 84. 
the comparison of the project of Saint-Die (Lo Corbusier) and the plan of Parma, or the strength association of The Uffizi plan in Florence and the volumetric plan of the Unité d'Habitation in Marseilles.

These two ideas can also be also linked to images of the same space, but taken in different periods of time (Figure 2). For example, the Agora in Athens during the Greek period in II siècle B.C. and its "transformation or adaptation" during the Roman conquest in II siècle A.D. are two completely different ways of conceptualizing, seeing and building space. ${ }^{7}$
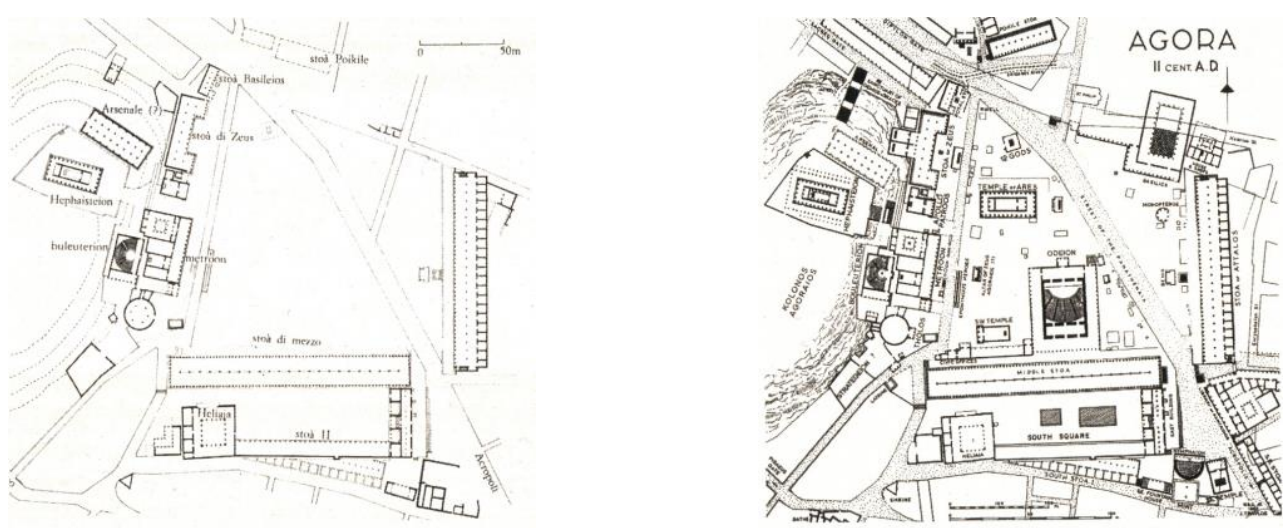

Figure 2. a) Agora in Athens. II siècle B.C. b) Agora in Athens. II siècle A.D. Source: El Vacio. Fernando Espuelas.

In the same way that we processed before the images of Parthenon and Pantheon, we could associate the image of Mondrian painting Boogie-woogie that traces the net of New York City with the chart of Gianbattista Nolli of Rome. Or this last one with the one of the contemporary Piranesi with its fluid Campo Marzio. ${ }^{8}$ Examples of solid and fluid spaces (Figure 3 ).
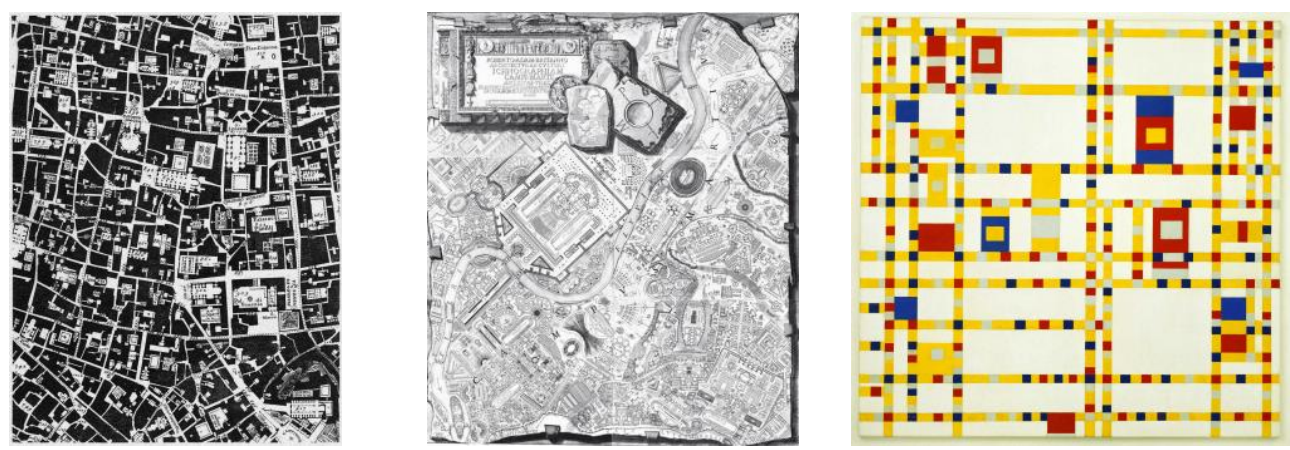

Figure 3. a) Nuova topografia di Roma, G. Nolli, 1748; b) Campo Marzio, G. Piranesi, 1762; c) Boogie Woogie, P. Mondrian 1942.

Source: a)Metamorfosi dell'Immagine urbana, Gangemi b) Il Campo Marzio, Ermes c)Mondrian, TAJ International.

7. Fernando Espuelas, Il Vuoto. Riflessioni sullo spazio in architettura (Milano: Christian Marinotti Edizioni, 2004), 54.

8. Mario Coppa, Storia dell'urbanistica dalle origini all'ellenismo (Torino: Einaudi, 1968). 


\section{The Pompeian House between Atrium and Peristilium}

The Pompeian house, or the atrium-peristilium house, represents an introverted residential model, which has only zenith openings. The presence of light, rain and wind have certainly a primary utility and a functional logic, but the presence of water inside the house, or the framed view of the stars overcome its utilitarianism and connect man with the essential aspects of life that go beyond strictly functional logic.

Both open spaces - the atrium and peristyle - constitute the basic binomial of a whole series of elements that integrate with each other, reaching a general composition and balance maintained together by the sequential perception of various interior spaces. The Pompeian house is by itself an initial fusion of that basic binomial $\mathrm{A} \mid \mathrm{B}$ combined in a kind of juxtaposition. The atrium comes from the ancestral Etruscan house, centred on its central space open to the sky that directly and vertically binds the individual to the absolute Cosmos.

The Greek peristyle offers a vision from a space covered but open to an outer space that, having the ambition to be infinite, extends horizontally and reproduces a micro paradise on earth. The peristyle resumes the concept of vegetable garden-garden (heredium), dragging a fragment of nature inside the house. Its origin is traced back to the Greek houses of Priene as the association of some of its spaces, in particular the colonnade of the megaron structure.

The empty-space of impluvium or compluvium, ultimately Etruscan atrium, refers to what is the conception of Roman space understood as a cubic vacuum (again the Pantheon) able to contain within a definite and geometric limit the void, as opposed to the peristyle of the Greek Agora (or the Parthenon), which show an idea of liquid space more conformable with the theory of neo-plastic idea. ${ }^{9}$

We are facing two flows that, if analyzed separately, move in opposite directions (it would be better to use the term distinct): the vertical, centrifugal and inclusive motion of the patio and the horizontal, elusive and centripetal movement of the pavilion.

The Pompeian house is thus constructed as if it were composed of two "completely" distinct parts (Figure 4). The first sector is associated with the patio, next to the entrance, carved in the mass, and its elements use Latin words such as fauces, atrium, ala, tablinum.

Going beyond this is the second part of Greek origin, with its elements lightly collocated in a fluid space: peristylium, exedra, oecus.

9. Joseph Rykwert, L’idea di cittá (Torino: Einaudi, 1981), 97. 

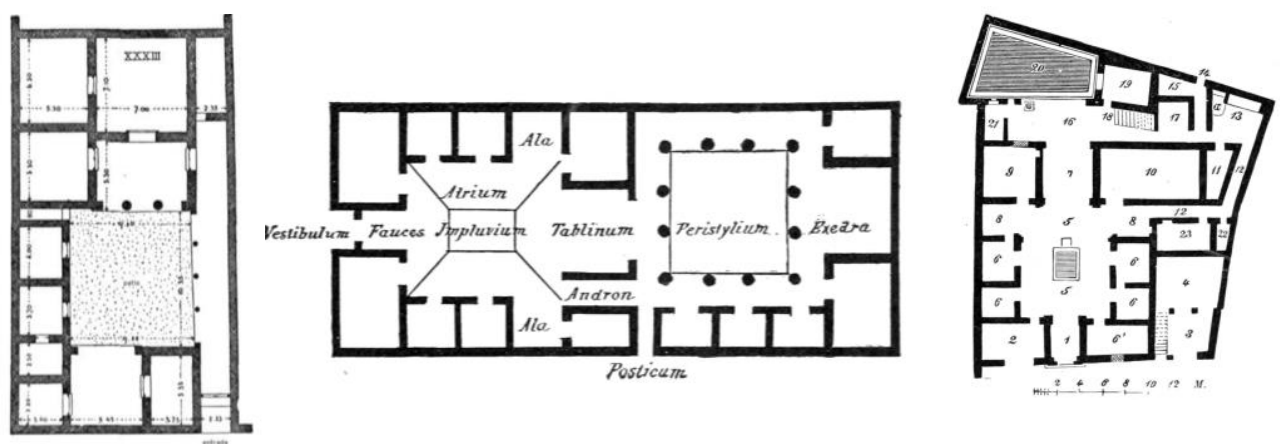

Figure 4. a) House XXIII Priene. IV Siecle AC b) House of Tragic Poet. Pompei C) Pompeian House as August Mau drawn Source: Pompeji in Leben und Kunst. August Mau.

Among the space proposals analyzed and compared in this essay, Barcelona and Poissy on one side and atrium-peristyle house on the other, there is a considerable gap of time separating them. We might assume that this fact prevents a comparison of the examples under consideration, and that the results of each one, if the results can be talked about, are as profoundly different from each other as the principles that generated them. Just think of the free plant, the systems of large windows, the freely placed planes, and the thin pillars of modern space, opposed to the "rigid" system of powerful load-bearing walls, the grooved columns carved from rock and mighty architrave. Yet, by combining these ideas, their constructive shapes, their formal configurations, one can build a possible common history, or at least a common path, where various figures pass through time using the same spatiality.

The ideas of the patio and the pavilion, as well as their spatial considerations, can be analyzed using two drawings that resume in only two images the characteristic that we established in the introduction of this essay. The Aldo Rossi painting of the project Monumento alla Resistenza (1962) is clearly the "A|patio" element while Giuseppe Capogrossi painting titled Temporale (1931) is the "B|pavilion") (Figure 5.) The two paintings collect in a few strokes the essence of the spirit of the patio and that of the pavilion.
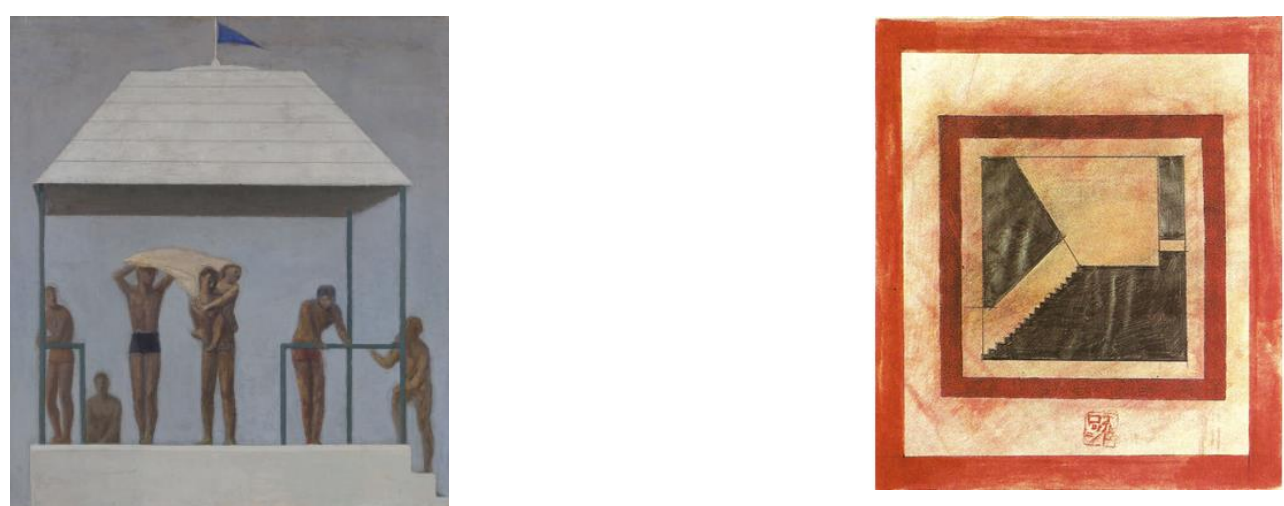

Figure 5. a) G. Capogrossi, Temporale; b) A. Rossi, Monumento Cuneo Source: a) L'effetto metafisico. Gangemi Editore B) Aldo rossi :Tutte le opere. Electa. 
During the thunderstorm, some figures are protected below an open, but covered, empty space that differs from the "rest" of the space with the presence of a cover and a podium. Lightweight tectonic Greek temples, devoid of stereotomic appearance, are a consequence of the use of stone. The fence of the monument hides a room that seems hypogean, which is accessed by ascension. This space is meant as a negative or mold of the pavilion cover, which remains overturned with respect to this. One repairs, slipping the liquids on the sides, while the other seems to want to collect it inside.
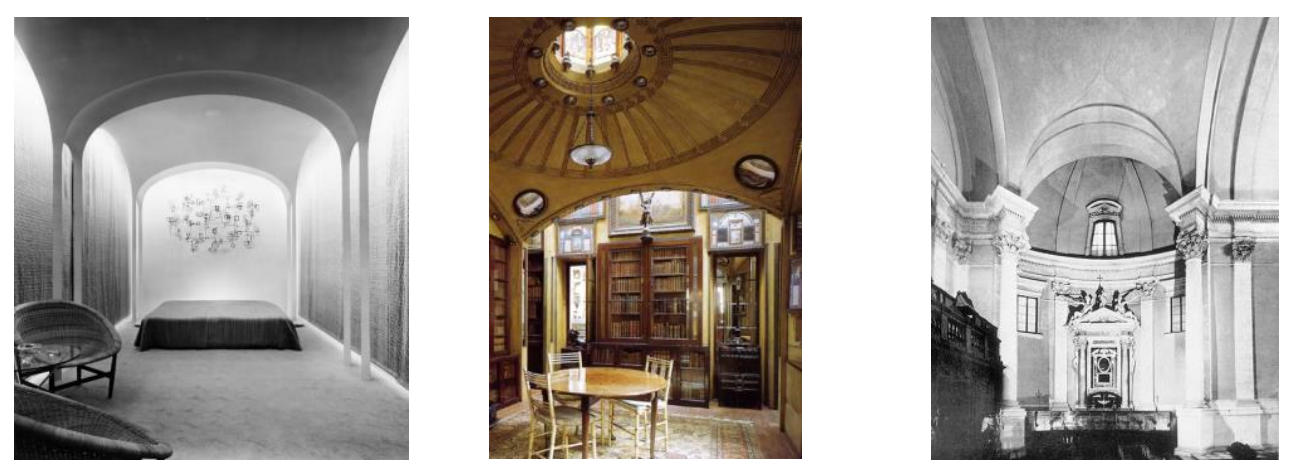

Figure 6. a) Brick House, Philip Johnson b) Lincoln Inn Fields, John Soane c) Sforza Chapel, Michelangelo

Source: a) The glass house org; b) Inspired by Soane, London Christofer Woodwart 1999; c) Alinari Archives, Florence.

This kind of comparison, which looks for similarities between different spatiality, is evident by comparing a whole series of examples and works that offer hybrid versions of the patio | pavilion. There is a relationship between images of Philip Johnson's Brick house with Soane's Tea Room and both with Michelangelo's Capella Sforza (Figure 6). It looks like, in this case, that is possible to melt in the same space Aldo Rossi project Giuseppe Capogrossi painting.

The common thread is always that of the hybridization of the patio and pavilion as ideas. On this guideline, which is not the direct object of the development of this text, we want to highlight some aspects that at a distance of 2000 years bind and link the Pompeian homes and those of the Modern Movement.

\section{Le Corbusier. Pompei and Poissy}

Le Corbusier's interest in classical architecture, and the ability to reelaborate the suggestions received and stored in architectural forms, is demonstrated in the drawings of his travels through Tivoli and Pompeii. These affect the conception of projects designed and built by him. For instance, the designs of the Silver Wedding House, read in parallel with those of Villa Savoye, offer a possible starting point to putting both works in relation to each other through the sequences of concatenated spaces, bound by a continuous 
alternation in the relationship between full and empty, covered and uncovered, internal and external.

In the sketch of $1911^{10}$ the entrance impluvium and the garden at the bottom of the house are two open and uncovered spaces that draw our attention. These are the points on which the eye focuses, thanks to the direct light coming from the outside. Later, as if the pupil's contraction allowed us to observe the shadow areas, we begin to see the aspects that these void spaces establish between them and the adjacent ones (Figure 7).

We compare this sketch of Pompeii, which is almost a "snapshot" with the image of the terrace/patio of Villa Savoye ${ }^{11}$ which is surely a more elaborate representation over time as well as conceptually. A precise design elaborated in the office.
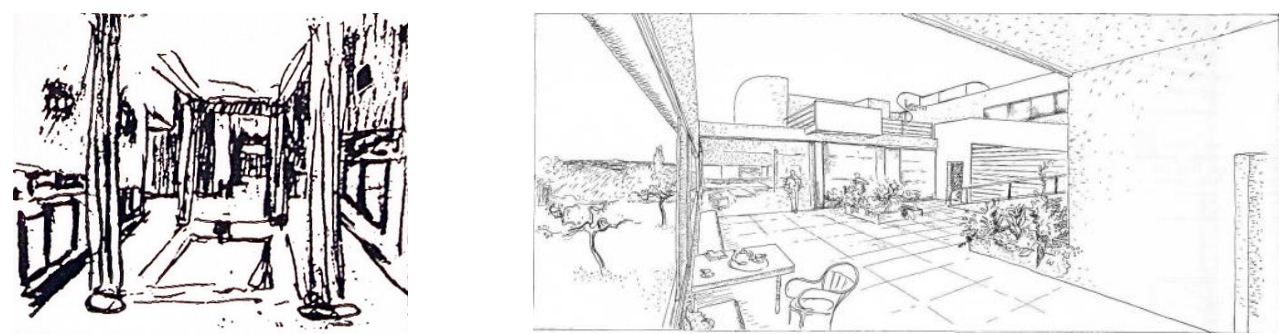

Figure 7. a) Silver Wedding House; b) Villa Savoye, Le Corbusier Source: Carnets No 4 Le Corbusier. Complete Works Vol. 1 Le Corbusier.

With this comparison we want to support the idea that there is a patio on the first floor of the Villa, but also that the two images tell the same thing. There is a similar space sequence in both works, consisting of a concatenation of elements composed of each other, fragments that build the whole.

To support the idea of the patio inside the Savoye villa it is useful to go back in time (Figure 8). Le Corbusier's projects organized graphically and according to a chronological temporal logic appear as a clear, well-defined closed series, using the concept and differences between series and sequence as George Kubler define in his writings. ${ }^{12}$ Each project can be analyzed both as a vision that looks to the past, by seeking motives and origins, and to the future, by analyzing the influences in later works. 126.

10. Le Corbusier, Carnets. Voyage d'Orient (Milano: Parigi, Electa, Fundación LC, 1987),

11. Le Corbusier, Janneret, Pierre: Oeuvre Compléte (Zurich: Les Éditions D’architecture, 1964), 126.

12. George Alexander Kubler, The shape of time (Torino: Einaudi, 1976). 


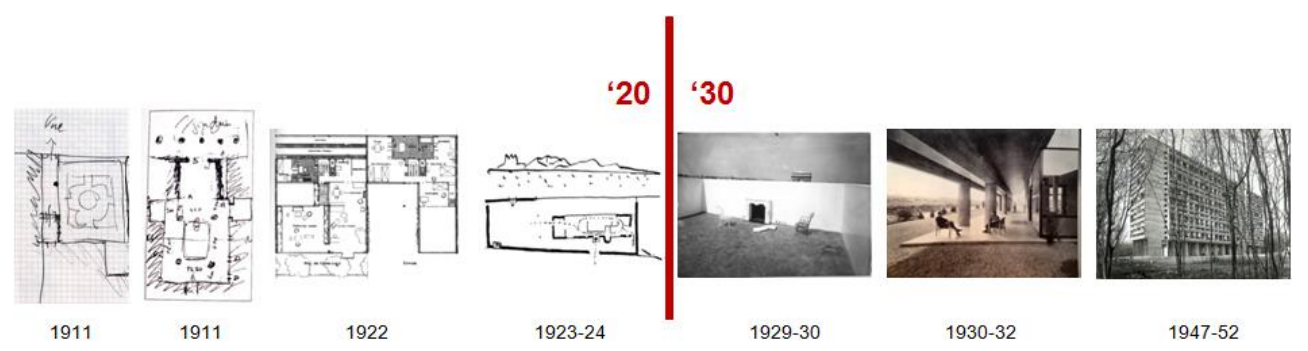

Figure 8. Temporary Sequence of LC Works Source: Author Composition.

The references to the patio are clear in the sketches of Ema. The experience in Tuscany brings its influence to the design of the Immeuble Villa, a project not built as a whole, but as a fragment in the pavilion of Esprit Nuveau. At the same time, this pavilion has clear references to the images we find in the beautiful Serapeo carnets of Villa Adriana. Spatial research is the same, as is the analysis that can be done by comparing the designs of the Immeuble Villa with those of Villa Mayer (Figure 9).
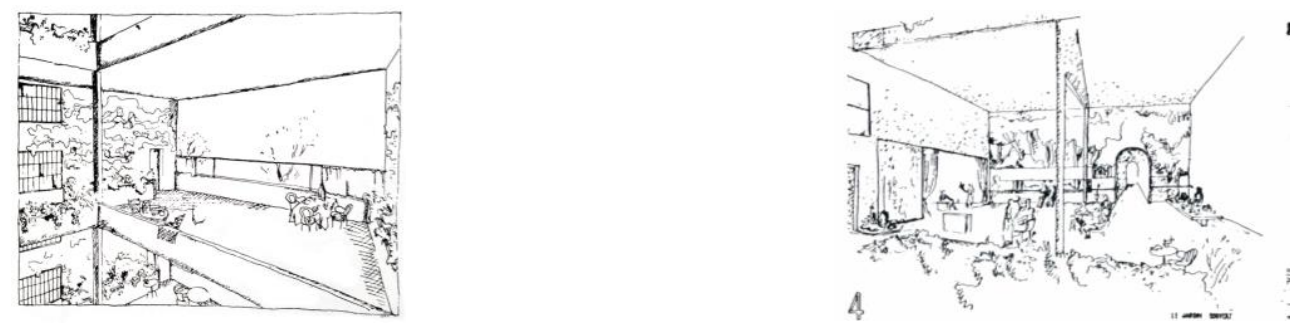

Figure 9. a) Immeuble Villa; b) Villa Mayer

Source: Complete Works Vol. 1 Le Corbusier.

They are all projects that are described from a point of view where the observer is located approximately below a covered and open space. From this resting and waiting space we observe and reflect on what surrounds us. Notice that the viewer's chosen point of view is always placed in the patio, almost suspended in the vacuum in a difficult or impossible position to reach in the reality of the work, if built. Yet, it is useful and perhaps necessary to describe as much as possible the overall idea of a project. In the description in Vers une Architecture ${ }^{13}$ of what Le Corbusier calls the House of Nuts in Pompeii, the path begins by leaving behind the road and then finding us at the atrium viewpoint and from there visualizes the other spaces that constitute the sequence analyzed. In the perspective of Villa Savoye, we can only find ourselves at the end of a just completed journey. It is not possible to materialize in that position except through a long and continuous journey that from Paris takes us up there. We turn our gaze to what just crossed, as if we were reassembling, within a single purist image, the individual environments and the many stages lived by moving in the house.

13. Le Corbusier, Verso una architecture (Milano: Longanesi, 1984), 149. 
It deserves to be underlined that such reflection is not entirely certain. At the point where we are placed, there was a proposal, in the version published in Volume I of the Complete Works, for a staircase that directly gave access to the garden, a sort of alternative route. Pompeii and Poissy offer a concatenation of spaces and space elements quite similar, despite the two thousand years separating them. Let us continue with the similarities. After the first space/patio open to the sky, ${ }^{14}$ as we have seen, follows a garden that lies at the bottom of the perspective. In the middle of these two empty spaces is placed the tablinum. Le Corbusier also places particular emphasis on the Villa Savoye in defining a clear, elongated rectangular space, which occupies completely a side of the villa, where the kitchen, dining area and lounge are in sequence, claiming and declaring some importance to this "function" compared to others in the house. In both cases, the "room", between a double lighting system and ventilation, allows high quality of designed spaces that reflects a distributive aspect within the patio house type.

The fauces/atrium/tablinum/perystilium sequence is further elaborated as there are some additional elements that lie in the middle and at the sides of these main components, such as the porch and the andrón. Further advancing toward the garden of the Pompeian house, and before diving into it (though it is an exterior), we notice that between the tablinum and the outer space is an environment that has its own thickness and autonomy: the porch. This filter manages the relationship between interior and exterior, Offering again to us a covered and open space, inside of which flows and enters the light coming from outside, Aspect that can appreciated by observing the end of the LC perspective and reading its words on Carnet $n^{\circ} 4$. "hauteur de cathedral/plein d'ombre et/ au fond l'éclat du / jardin." ${ }^{\text {,15 }}$

At Poissy, the thickness between the inner "colonnade" and the façade plan, which accommodates the ribbon window, is similar to that existing in the intermediate space just described in Pompeii. A filter, an intermediary element between the interior and the exterior, compensates for the twodimensionality of the skin of the casing, almost comparable to the light and nearly impalpable closures of Japanese architectures. This need for "thickness" is evidently sought through the construction of the long support plane, which runs parallel to the window from kitchen to fireplace, as well as by the structural overhang that is produced on only two of the four sides of the perimeter of the building.

It is defined as a sort of thick frame, which acts as a filter, a mediating element between interior and exterior where the light bounces and takes body.

In spite of the apparent two-dimensionality, we find in Le Corbusier's work a series of details that are fundamental to the perception of space. Such attention to the elements that introduce vibrations in the passage and transition between space and another are detectable by few, but fundamental, details of his travel notes. The section, the plant and the perspective of the Silver Wedding

14. Le Corbusier, "Ciel Ouvert," as described at Carnet $n^{\circ} 4,126$.

15. Le Corbusier, Carnets. Voyage d'Orient, 1987, 126. 
House reveal, for example, an investigation into the full/empty filter element, consisting of the wall and the openings, which communicate or separate the colossal vestibule from the garden. Despite its simple configuration (a rectangle cut out in a wall), it is fundamental to the overall construction of space intended as concatenation of successive environments. Concatenation is even more complex as the movement between the two spaces is possible in Pompeii both through the large aperture positioned almost centrally with respect to the main axis of the whole house, as well as through the small opening that enters the long narrow corridor defined as andrón, positioned on one side of the tablinum.

At Poissy around the suspended patio, on the opposite sides of the ramp, we find at least two spaces that open toward the central empty space facing one each other. L'abri (refuge/shelter) as indicated in the plan is a further pavilion in the pavilion. This space, from which we observe the patio, is composed both in section as plan by a ' $\mathrm{C}$ ' shape that encircles us on all sides as well as around our feet and head. On the opposite side, another ' $\mathrm{C}$ ' of identical dimensions (if we compare sections) has the same openings arranged on its vertical surfaces. The substantial difference between the two spaces is determined almost exclusively by the presence or absence of glass.

The fenetre en longueur cuts the box of the building independently and indifferently from the fact that a glass should be placed or not. It might be absent, and basically the relationship between inside and out would remain unchanged. Besides, glass between the walls of Pompeii is not found. Glass is needed for protection from wind, temperature or rain, but it could be ignored if it was technically possible. It is not a constructive, tectonic material with which to create spaces as we can see in Mies's work.

In LC's work, the glass is transparent and nothing else. However, this observation implies a further reflection on how succession and transit between spaces involving inside and outside, an interior and an exterior, is produced. The transition between one another is in many cases syncopated, continuous, but not fluid and homogeneous as those who belonged to the Neoplasticism Movement were hoping. Just think about the ramp, a symbol of the promenade, divided between a ground floor (inside) and a second (outside) where the transition between the inside and outside, as a knot through which we must necessarily pass, is placed in the patio. In this case, the demarcation line is precise and clear, without any element of thickness that functions as a bearing.

Reconsidering the two drawings from which we started, in an attempt to tie to the examples of the past the evolution of those present, the alternation of full and empty is established with different gradations in the play between lights and shadows. In the background in both representations, an open and bright space is announced. In the Campania case, there is an open space surrounded by a well-defined fence, which allows for control and sets limits to a fragment of nature. A garden, what we meet after the porch, refers to a domesticated, familiar and intimate nature, well distinguished from the relationship that is established with the outer space, which we perceive from the first patio, where it clearly "cuts" a portion of sky/heaven into this open- 
air room. A fragment of celestial vault attracts us upward in a relationship of verticality with an infinite elusive.

In Ville Savoye, at the level of the patio and the solarium, the relationship with nature and outer space is told in three different ways. A first fragment of outer space appears at the end of the perspective in one of the ribbon window modules inside the salon. Framed in the window looks like a frame inside another frame; it does not appear to belong to the same landscape that closes and delimits the left side of the sketch box. This constitutes the second fragment of nature present in the composition. In this case, as in the other project windows, the ubiquitous landscape becomes part of the interior composition of the house. The last and third mode is that of the sky of the patio. Unlike at the house in Pompeii, ascending to a higher position, far from the ground, is not impossible. The climb is less sacred; it is more profane.

Spatial continuity, understood as the appropriation of the vacuum space of nature, must be sought in the internal verticality, and in particular in the ascending movement between the various levels. The external natural void is juxtaposed to the interior space-void, which is the one that is really viable and usable by the man, enclosed within the lecorbusierian box. The external (nature)/internal continuity should not be searched infinitely in the horizontal sense, but rather, as indicated above, in a vertical direction. The vision of nature is contemplative, and it is produced only after we are introduced into the house and after climbing at least one level above the horizon line. These are partially true statements because we know the value of the plan/piloties space, of its role within the general conception of many Le Corbusier buildings as mediator between interior and exterior, as a fluid thickener that, starting from here, is introduced into the house, solidifying in space-void.

In the French villa, the sequence of spaces is clear: covered space | open space; uncovered space | patio; covered space | dining area; open space | nature garden.

In the Pompeian villa, the space sequence is clear: covered space | open space; uncovered space | patio; covered space | dining area; open space | nature garden.

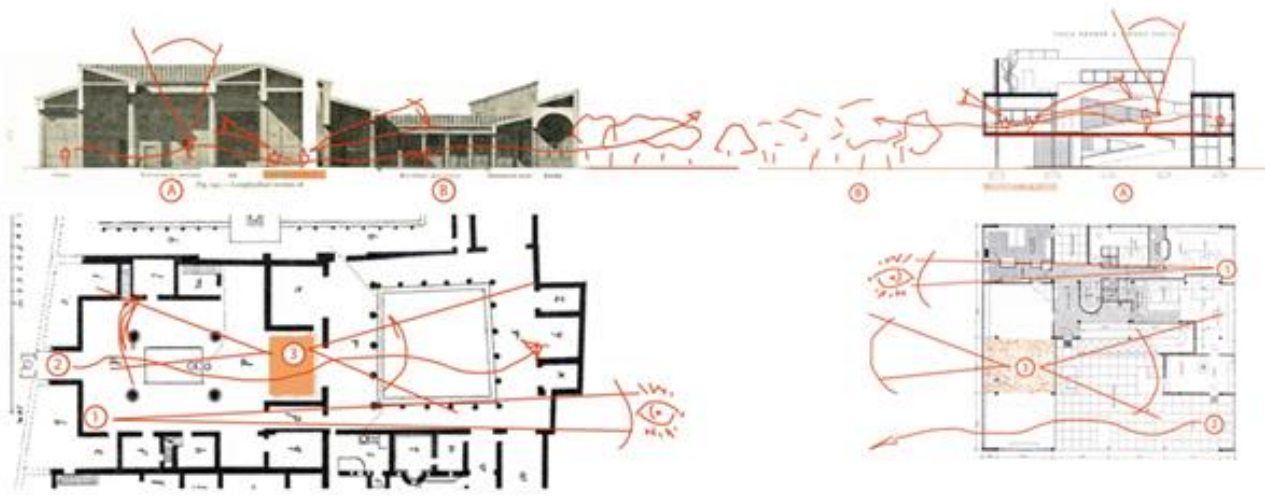

Figure 10. Comparison between LC Composition Spaces an Pompeian House Source: Author Composition. 
The elements analyzed and searched within the two plans and their sections are always the same: the main points of view, possible sequences of spaces through the use of the gaze and movement of the body, constituent elements. the time-space sequence emphasizes the position of the tablinum as a hinge between the two main "open" spaces. In the Pompeian case, the concatenation between a space and another, between an element and the next one, coincides with the real crossing of the building by a user. The visual axis coincides with that on which the various elements of the composition are engraved. In the case of LC the paths are multiple, not unique, due to the distribution of paths and space elements on multiple levels. Nevertheless, once placed in the main point of view, below a covered space similar to the fauces, the sequence is quite similar to the Pompeian one. In the case of Mies, there is often a ninetydegree rotation between the main access axis and the sequential axis of the spatial elements, which converge into the tablinium. These are basic operations that are moving the same Lego pieces, but generating numerous diagonal visual that together with the movement make the recognisability of the "simple" spaces, organized clearly in the plan, very complex (Figure 10).

\section{Mies. Pompei and Barcelona}

The flexible model of the Pompeian atrium-peristyle villa, read by using the patio | pavilion binomial, allows us to solve some of the themes that Mies poses, in particular after the construction of the brick house and before long series of experiments with patio houses of the '30s.

As we will see, it is about taking some parts, looking at them and recompiling them in a different way. The temporal sequence of some of Mies's projects, unlike Le Corbusier's, does not offer a vision of continuity and concatenation, almost cause and effect, in the search for references and successive solutions (Figure 11).

His projects are dancing stars and burst into the architectural scene with no clear previews. The Barcelona Pavilion, as far as it he wanted to make it reference the Neoplasticism Experience, seems to be an anticipation of the design of the patio houses after 1929. Berlin's Neue Galerie also appears in 1968 as a new leap, this time backward after the American experience, in its production that has to do with the patio and pavilion.

The Barcelona Pavilion, not only for the title, could be considered the emblem of this archetypal idea. Therefore, we may feel confident in finding in the building the principle stated as the essential object of the project. 


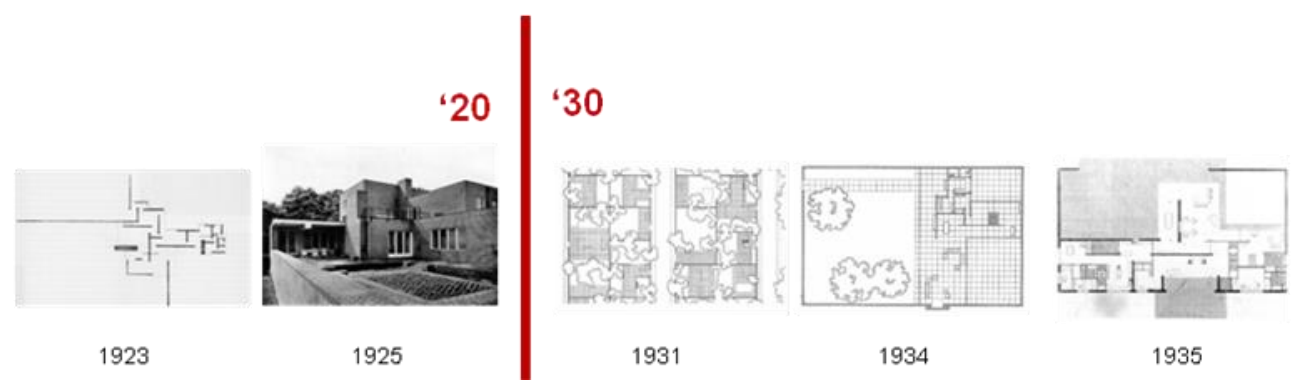

Figure 11. Temporary Sequence of Mies Works

Source: Author Composition.

Richard Padovan coincides the work of Villa Savoye of Le Corbusier to that of a pavilion placed in nature, a universal volume, precise and cubic, in which is inserted inside, in an unequivocal manner, the figure of a patio. Regarding the project of Mies, reversing the archetypes used for analysis of the Villa, he states that the building constructed for the exhibition of 1929 in Barcelona "is a patio in a pavilion". ${ }^{16}$ The project is therefore a pavilion and at the same time is clearly surrounded by a series of walls that delimit an empty portion of void, strategic action that, among other things, points to the idea of a patio. It seems that you are in a situation where you say only pavilion when you think also on the patio. These considerations begin to waver our initial security due to the name, which indicated "textually" that Mies's project was a clear architectural proposal of a pavilion.

The hypothesis of Padovan opens to a very complex and intriguing development of the work's analysis, which makes it necessary to find out the constituent elements of the project, which appear together and at the same time in the final composition. These elements, if analyzed individually, reveal a close resemblance to those that "build" the Pompeian home. Initial intuition is alongside this hypothesis, perhaps even more striking.

The patio houses of Pompeii, which provided a key element in the construction of many projects of Le Corbusier and Mies van der Rohe, are the basis of the many arguments that led to the construction of the Pavilion of Barcelona, and hence to the production of some of the projects of the 30's. This is a theme common to the two great M.M. masters, which opens space to the paradox, by converging two spatial proposals commonly understood as divergent and opposite.

In the later project of the Hubbe House, this may be more evident, for example the use of the some elements of the Pompeian house, like tablinum/ atrium/peristilium, organized in a different way. The first aspect is the drift of the patios pushed to the "borders" of the composition by a centrifugal force revolving around the tablinum. In the Neue Gallerie the patio, in a reversal between full and empty, will return to the centre (Figure 12).

16. Padovan, "El pabellón y el patio. Problemas culturales y espaciales de la arquitectura De Stijl," 1955, 18. 


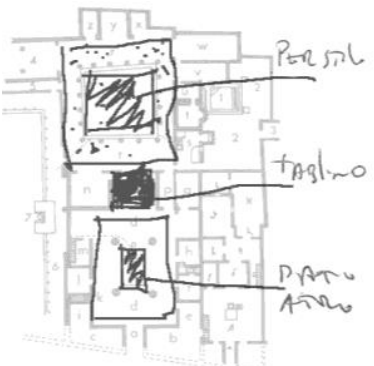

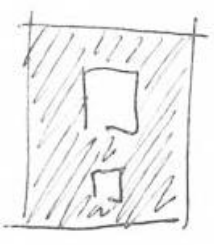

PonPel

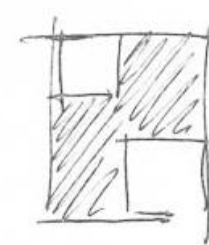

CASA PATO

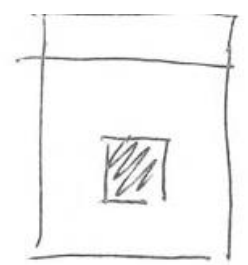

N. Gaker E

Figure 12. Comparison between Elements Position of Pompeian House and Patio House and Neue Galerie in Mies Source: Author Composition.

The sketches produced by Mies reflect this search for a promenade hit by that force and the exploration of different perspectives always changing (Figure 13).
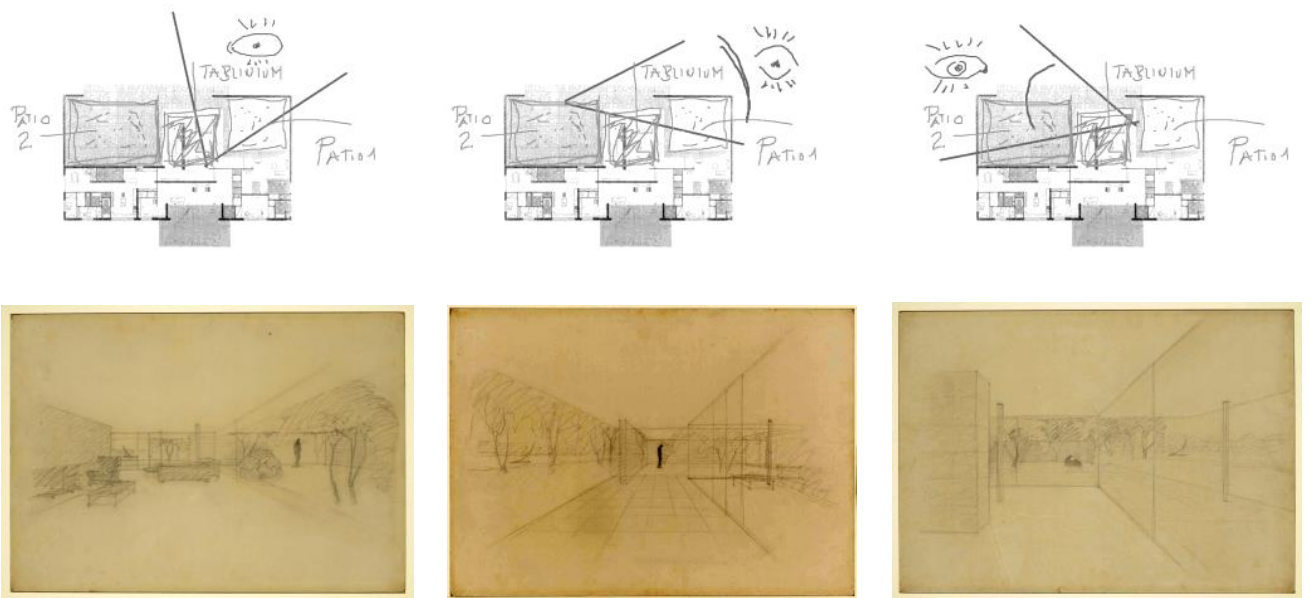

Figure 13. Sketches of Mies Associated to his Position in Architectural Plan of Hubbe House

Source: Author Composition, and MoMA of New York.

As we said, it is evident that the interest in the type of patio can be most clearly seen in Mies's thinking from the construction of the Barcelona Pavilion onwards. This idea acts as a point of inflection between the influences of neoplasticism and the use of models reproduced by the classical tradition, and in particular by Schinkel. The appearance of the Pavilion in 1929 clearly marks a first period (the decade of the 1920s) and later period (the decade of the 1930s) in the architectural production of the German architect. The use of the patio, although its typology may be considered characteristic of areas close to the Mediterranean, can be found in much of Nordic architecture. Alvar Aalto and the architect Oiva Kallio (where studied Aino Aalto) should be briefly 
remembered. ${ }^{17}$ Among these architects, it is possible to weave an interesting wire in the use of the patio idea, associated with the idea of the isolated pavilion, contextualized in the Scandinavian ambience and within the Modern Movement. Furthermore, a second course overseas could lead us to the works of Rudolf Schindler (and therefore Wright) in the United States and those "binuclear" by Marcel Breuer so described by Marti Arís in a fusion of references to the patio and pavilion. ${ }^{18}$

Barcelona's pavilion, although it is not a home, has often been considered similar to this for its relatively domestic dimensions. It was not conceived as a pavilion for exhibitions, but as a symbolic home that expressed the refined culture of Weimar. In the words of alumnus at Bauhaus Howard Dearstyle, Mies said, "If you are able to solve a project house, you can solve whatever else."19

The house is a constant presence in the projects of those years, and Mies shows interest and passion for this theme in a distinct form from Le Corbusier. Both architects saw something in the classical style to be loved. Tradition was not to be considered fixed, immutable and belonging to the past, but a material that survived by transforming it and reusing it. ${ }^{20}$

The design of the brick country house of 1923 is opposed to the spatial idea of patio, as it seeks out its continuity and fusion with infinite space and on the absence of interruption between interior and exterior that Bruno Zevi sees as a conquest, materializing in an explosion to the outside of its interior spaces. ${ }^{21}$

Using the wall as the main formal solution refers to the will to establish precise limits of a clear boundary domain opposed to the demands of the neoplastic movement. Through this project, "Mies has produced an unresolved conflict between two types of home: the one like a pavilion and that of a patio." ${ }^{22}$

The idea of the patio or enclosure, defined by the wall that shifts on itself, appears in the Pavilion in a brutal way, offering a reverse proposal, diametrically opposed to the walls of infinite length of the brick home drawn a few years earlier. The synchronous use of the two archetypes offers a solution to the problems posed. Without the project of the brick house and theoretical contributions and reflections around the De Stijl movement, the appearance of the Barcelona Pavilion on the European scene would be incomprehensible. Without the contribution of the patio, it would be even

17. Gonzalo Díaz Recasens, La tradición del patio en la arquitectura moderna Patio y Casa, DPA n 13 Departament de Projectes Arquitectònics (Barcelona: ETSAB UPC Edicions UPC, 1997).

18. Carlos Martí Arís, La casa binuclear según Marcel Breuer: el patio recobrado. DPA: Documents de Projectes d'Arquitectura", N.13 (Barcelona: ETSAB UPC Edicions UPC, 1997), 46-51.

19. Cristina Gastón Girao, Mies. El proyecto como revelación del lugar (Barcelona, Caja de Arquitectos, 2005).

20. Kennet Frampton, L'altro movimento moderno (Milano: Silvana Editoriale, 2015).

21. Bruno Zevi, Poetica dell'architettura Neoplastica (Torino: Einaudi, 1974).

22. Padovan, "El pabellón y el patio. Problemas culturales y espaciales de la arquitectura De Stijl,” 1955, 25. 
more incomprehensible as this dancing star has appeared in the scenario of those years.

The Barcelona Pavilion contains many aspects that we define as architectural constants, which are later found in the production of patio houses, both from the point of view of the typological elements, as well as the spatial strategies used for the composition of these elements.

It is useful to say that the architectonical space for Mies is mostly a volumetric definition, rather than a special delimitation. In this sense, the patio it is not a confined space; it is volumetrically still open to the surrounding elements of the composition, and in many cases playing with internal/external situations. This implies connections with the landscape and from this point the connection with Nature. ${ }^{23}$

In the works of Le Corbusier as in Mies there is a common goal, also found in the Pompeian houses: all "are pursuing a sequential perception of the inner space associated with long perspectives that, very often, embrace the total size of the house." ${ }^{24}$ Revetlatt uses the concepts of symmetry and eurhythmy, from the Greek world, to give a coherent answer to the principles of aggregation of the elements that make up the Pompeian house. The elementary elements that we list of the Pompeian house are generally definable as symmetrical figures: the rectangular or square patio, peristyle or other regular structures that define the general composition.

What defines the concept of eurhythmy is relative to how they fit into the plant. Although Mies begins with isotropic modular structures, the final space configuration does not respect a single main axis, but identifies more directions, within its plots, which often intersect with each other producing sharp changes in direction and points of view.

Mies's space operation in Barcelona is composed, in this case too, of two ' $\mathrm{C}$ ' faces in the plan of the building defining the first gesture of appropriation of the void. Reasoning could also start from the two pavilions that relate each one with a folded wall segment. The reasoning could also start from the two pavilions that relate each one with a bent segment of the wall, defining, through their covers, precise and protected areas. Each of these double compositions is associated with a patio. The operation, the creative act, the initial big-bang, could also be sought in the elevation of the base, and in the identification of the two peripheral patios, as is the case in the design of the house of the two patios of 1934.

23. Fritz Neumayer, Mies van der Rohe, la palabra sin artificio. 1922/1968 (Madrid: El croquis ed. 1995).

24. Pere Joan Revetlatt i Mira, La casa pompeyana: Referencias al conjunto de casaspatio realizadas por L.Mies Van Der Rohe en la década 1930-40. Doctoral thesis (Barcelona, 1993), 158. 

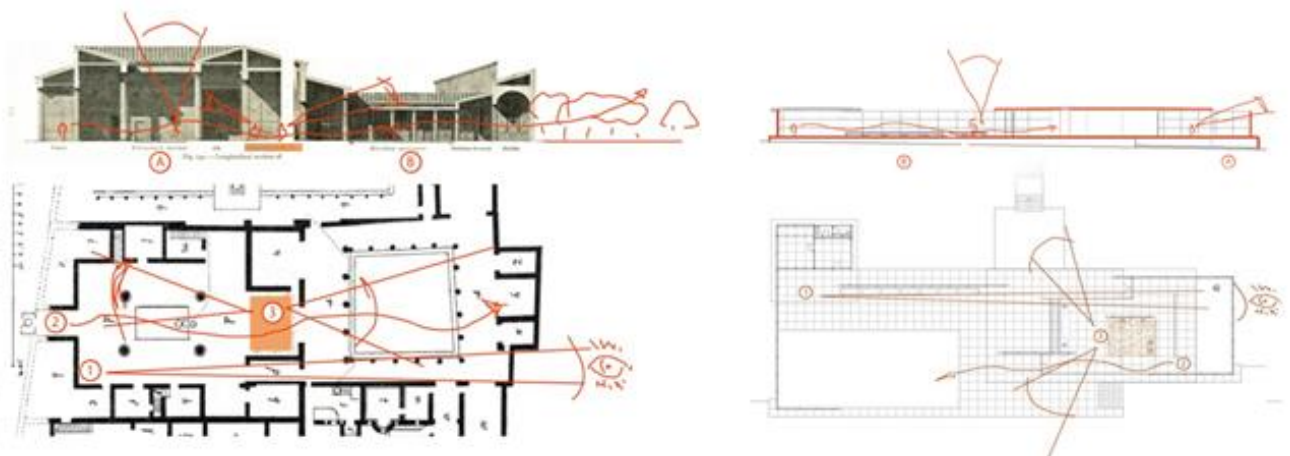

Figure 14. Comparison between Mies Composition Spaces an Pompeian House Source: Author Composition.

The pavilion, according to many, is a masterpiece because it is loaded with ambiguity and contradictions that lead to a mestizo situation, due to the mixing of different genres that produce a hybrid result. "Masterpieces hate too much clarity of intent and form unity." ${ }^{25}$ In the Savoye Villa as in the Barcelona Pavilion we can recognize the presence of an ordered nucleus of columns circumscribed by a perimeter in consonance with their formal disposition.

In the Ville Savoye the perimeter clearly matches the skin of the building, although on the ground floor the porch in the form of ' $\mathrm{C}$ ' has a certain amount of ambiguity. The pure and perfect regulating grid concept is modified by intrusion of the stairs and ramp nucleus, which produce new vibrations. In the Mies project, the structural grid (especially the steel columns that Wright criticized so much) retains its purity and geometric rigidity, keeping a precise rectangle slightly suspended, a horizontal plane in the air, who wants to get out of the vertical walls. Underneath the roof are enclosed but open spaces and "interior" enclosures like air bubbles, which we can consider closed.

The perimeter is, however, very ambiguous, and despite the two ' $\mathrm{C}$ ' are clear, which in the plan embrace the building, the central area is open towards the exterior space. The limit, the differentiation between what is internal and what is to be considered external, is entrusted to the base, which is accessed tangentially by a few steps, perpendicular to the apparent crossing axis on the shorter dimension. This elevated surface is entirely crossable except for the mirrors of water that overlap the spaces we can call the two patios of different sizes, associated with the ' $\mathrm{C}$ ' wall configurations. With Le Corbusier we have observed that the views of his drawings are placed on the patio itself, and that this is often a viable, liveable space. With Mies, the opposite seems to happen. The patios refuse the presence of man and the points of view chosen to tell the projects look to the patios, but they are not occupied by human presence.

Mies maintains in balance the elements, the planes of his composition, in a musical spacing - pause by two notes - that might disappear at any moment. At the same time, the balance achieved seems eternal and the void passes in

25. Luigi Prestinenza Puglisi, Mies Saga, Personal web page. Prestinenza.it. 
between characterizing in one of the two spatial components. Le Corbusier instead compresses, encapsulates, and rationally rearranges its elements so that they fit within the reference spatial box.

In the analysis of the Barcelona project we find valid the observations made on the association of this plant with those atrium-peristyle Pompeian. There are some visuals that embrace the entire depth of the building. What is evident is non-sequential "direct" and "univocal" among the elements that make up it, mainly due to the drift of the patios towards the perimeter. There are scenarios, basically due to the presence of water, which prevent us from reaching the "bottom" of the enclosed space, forcing us to turn on ourselves, building a situation of continuous suspension and movement. The multiplicity or duplicity of the elementary "pieces" with which Mies makes up his own plant remembers, rather than the House of the Silver Wedding, that of the Faun. In fact, at the Tuscan atrium, a second tetrastyle atrium is added; to a first peristyle, follows a second, multiplying sequences and possible views in a mirror game. Nevertheless, the components that lead to spatial wealth are basically the same. The dissociation of parts in the proposed scheme of Mies's plan reveals the basic of its components, which, organized in succession, seem rather an abstract framework (Figure 15). The final composition leads to a high and intriguing complexity. With few strategic elements/full- spaces, the strength of empty spaces is revealed.

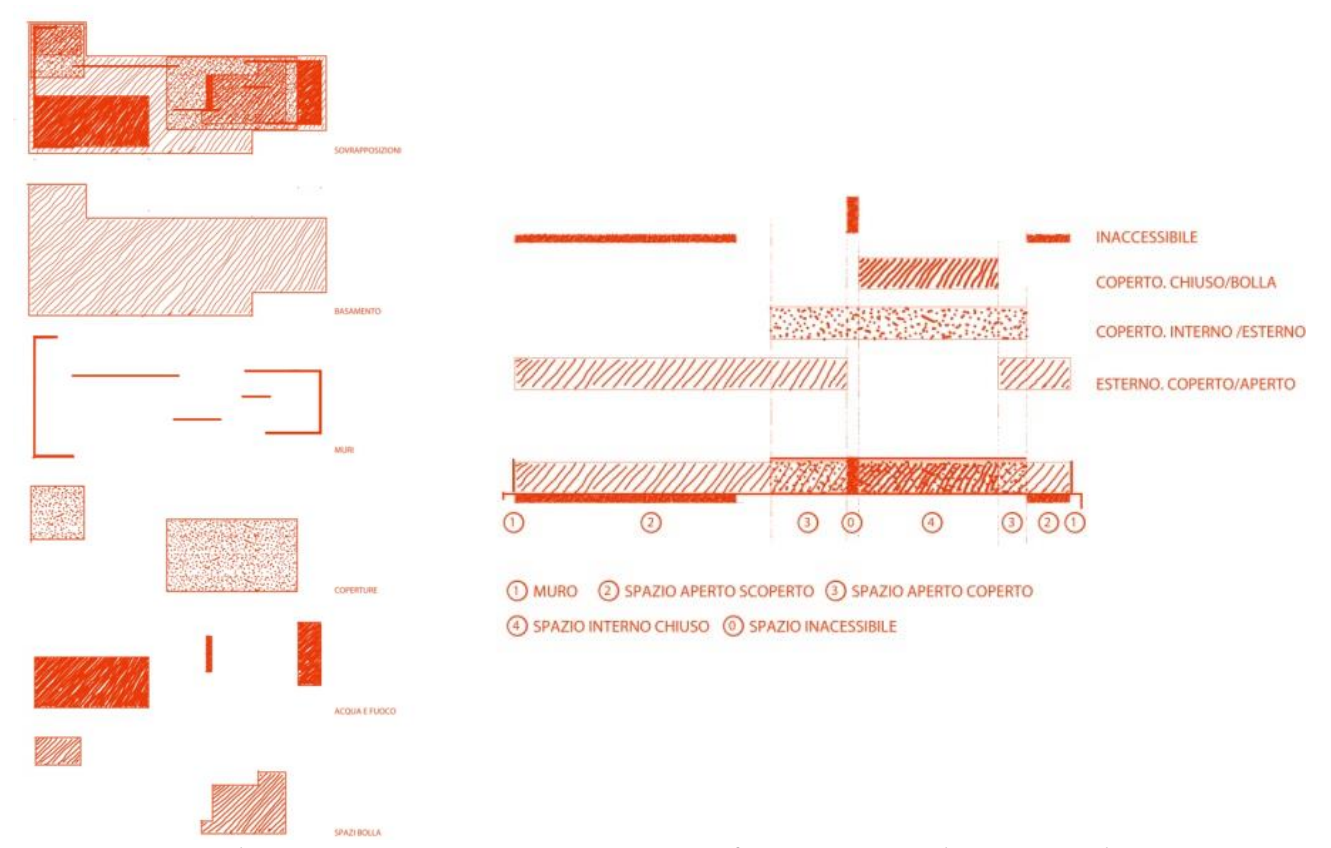

Figure 15. Elements. "De-composition” of Mies Barcelona Pavilion Source: Author Composition.

The pavilion, in a process of disassembly and replacement that history has accustomed to, is subdivided into some of its components, which we consider to be important or at least useful to our reasoning. Geometric and graphic overlays show some areas of the building where at least two distinct 
elements coexist and occupy overlapping the same space. From this action emerge open but covered areas. These are spaces that open mainly to the outer space horizontally, in the form of ' $\mathrm{C}$ ' lying on one side.

We choose a sequence that allows us to "cross", from left to right with respect to the plant, the entire building aside: wall (first ' $\mathrm{C}$ ')/space-coveredopen (first pavilion)/space-discovered-open (first patio)/space-covered-open (area underneath the roof but open to the larger patio)/space-covered-closed (the inner bubble)/space-covered-open (area below the roof but open to the smaller patio)/space- discovered-open (second patio)/wall (second 'C'). Such analysis can be repeated in Pompei's patio houses (fauces, atrium, tablinum, peristilium), as in Villa Savoye. However, in the comparison, it surprises the generic rectangular form of all the elements that make up the Pavilion. Therefore, their symmetry or mirroring when compared to the wealth of spaces and asymmetries that the overall space conception allows to obtain is also suprising. If we conduct an analysis of these compositional schemes, following the principles of symmetry and eurhythmy, we find a series of axes that are associated both to the general composition as well as to the possible paths of the user. This formalization of space, linked to the temporal space sequences of the constituent elements of the project, has the objective of reaching an overall image of the same. The alternation between full and empty, the variation of the luminous intensity, the concatenation of the spaces is extremely rich and varied.

Other reflections and further reasoning are possible. Padovan identifies a focal point of the project, which we can associate with the tablinum, as the area highlighted by the carpet near the onyx wall and the two chairs collocated by Mies. A fence (the one of the carpet) inside the fence is highlighted by the bubble enclosed beneath the roof, in turn inside the same perimeter of the two ' $\mathrm{C}$ ' walls, a space that is itself circumscribed by a further space, still surrounded by a wall fence. The carpet also recalls the mosaics that mark and put in relief significant areas of the Pompeian house, as well as the carpet on the sand in desert tents. The image of the tabernacle, which travels in the desert and is constructed and dismantled precisely by the modularity of its elements, is a convincing hypothesis of the relationship between this building and the pavilion or tent. The holy hall and then the most inaccessible hall remind us in part of the cell of the Greek temple and Le Corbusier's designs in Towards an Architecture. These are ideally reconstructed with the two ideas of patio and pavilion.

\section{Conclusions}

The proposed idea of analysis of space, based on the use of two archetypal images, is based on the paradoxical affirmation that the full is not to be understood as the opposite of empty, or that black is the opposite of white, but that each one has to be understood as a material, an entity with its own autonomy. In the architectural field, the idea of defining a vacuum as an immaterial material always available as material matter seems to be suggestive. 
The matter with which space is built is therefore a synthesis of two elementary components that we define as full volume units and empty volume units.

The vacuum is full and exists independently of us, while space does not. Emptiness is not space, though space may be empty.

Both terms of a binomial, composed of full and empty, come into play in defining a sequence of intermediate space situations where these extreme "ideals" must necessarily be considered. In the analysis of "real" situations, we find them only as components within hybrid forms, which cannot be explained by the contrast of the terms, but by the synthesis and the interpenetration of these.

The goal was to build a reference paradigm useful to understand reality, or at least a fragment of it. Within such hypotheses, the pair made up of patio and pavilion, intended as archetypes, understood as archetypes, enter into action by acting as interpretative support tool of reality, and as a model for the transformation of this.

It is useful to propose the use of the patio and pavilion in order to provide a solid shared starting point within the architectural discipline, a constant reference to the reading of some works, a possible interpretation of reality that is, however, constantly questioned and therefore changeable.

The entire essay promotes a double movement that once start from the identification of some "elementary" pieces and then goes towards "complexity," while the second operate in the reverse way. The sample tubs of a lab that we analyze are always in a mestizo situation as Martí Arís argue. The analysis that we promote utilizes a double movement across the world of architecture. The first one proceeds from elementary pieces to reach extremely complex structures through the operation of the composition. The second begins with the works in their complexity to lead us to the constituent elements of these, to the essentials. "The first movement allows hybridization, the mestizo. The second in turn tends towards the purity of the roots, to the distillation of the basic elements. In spite of this, it is nothing more than a new starting point for other mixing actions." 26

Starting from these premises, two works, built in 1929 in Barcelona and the other at Poissy, were analyzed using the archetypal idea of patio and pavilion that produces an evocative wealth of suggestions, and activation of interpretative and constructive processes. One could argue that the first project is not a home, and that it has been reconstructed and therefore is a copy of itself. The other could be said to have been inhabited in a "difficult" way, and that the same work has been saved thanks to the intervention against demolition by the same author.

The analysis becomes even more impressive when the study is not limited to the treatment of each building taken individually, but when comparing, in a binary reading, several cases of research, investigating common sources,

26. Martì Arís, Pabellón y patio, elementos de la arquitectura moderna (Bogotá: Universidad de Colombia, De Arquitectura 02, 2008), 27. 
especially in using the atrium-peristilium house, and effects after their construction (Figure 16).
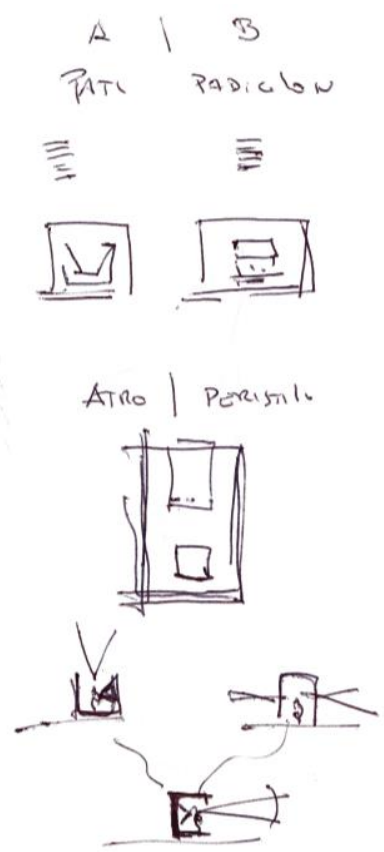

Figure 16. Bipolar Approach Following Two Archetypes and Synthesis. "C" Scheme.

Source: Author Composition.

The patio, the "way of building" defined by Antón Capitel as "that of the ancient, claustral system, ${ }^{27}$ is a central archetype in architectural production. We can consider it dominant until, in the $16^{\text {th }}$ century, it was absorbed, both physically and conceptually, by another method. This was explained as a composition system for elements or parts ${ }^{28}$ always from Capitel, identifiable in the pavilion house.

There are therefore two large blocks, to which we can constantly refer, that can be schematically differentiated over time, not so much for the total absence of one of them, but for a different intensity of use and presence in the works produced. The construction of space by the logic of the pavilion is probably the one that has been chosen in the last century, but it has been used in a reduced, short and individualistic form. It has lost in wealth of references and in complexity and intensity, reducing its basic principle to a simple volumetric calculation of a casing.

It has become an insensitive model of the space-void appropriation as an action in building space in particular in the complexity between interior and

27. Antón Capitel, La arquitectura compuesta por partes (Barcelona: Editoriale Gustavo Gili, 2009), 17.

28. Capitel, La arquitectura del patio (Barcelona: Editoriale Gustavo Gili, 2005). 
exterior. Many of the environments in which we nowadays translate with intolerance and irritation have been built for those who still have the ability and the desire to reject them or at least challenge them.

The proposed research is concerned with highlighting those architectural cases in which both binomials (at the same time and in the same project) can be seen as tensions that have been able to produce a great deal of significant spatial proposals. Projects we hypothesize are still useful in producing new reflections and opening up new opportunities for criticism and design, in continuity and consistency with the reported path, which combines and blends within the possible spatial views the ideas of patio and pavilion.

Some of the principles of the pavilion, as previously mentioned, seem to reflect the dominant features of contemporary architecture, and consequently all this seems to imply the exclusion of the patio from its production. However, the study highlights how both the patio and the pavilion, understood as formal concepts, continue to be present in numerous works by leading modern architects. The presented work is linked to a research path and seeks to demonstrate how the idea of space can be closely related to these two concepts.

The patio and the pavilion are proposed as part of the study objects of this work, through which it is possible to observe various works of architecture, in the continuous quest for relationship, pursued by man, between inner space and outer space. An investigation that always confronts the interior "I" with the external "Nature" through a path is materialized through the construction of the vacuum.

\section{Bibliography}

Agamben, Giorgio. Ninfe [Nymphs.] Torino: Bollati Boringhieri, 2007.

Capitel, Antón. La arquitectura del patio [The architecture of patio.] Barcelona: Editoriale Gustavo Gili, 2005.

. La arquitectura compuesta por partes [The architecture composed of parts.] Barcelona: Editoriale Gustavo Gili, 2009.

Caradente, Giovanni. Chillida Hierros de temblor II [Chillida Tremblings irons II.] Bilbao: Bilbokp Arte Ederren, 2015.

Coppa, Mario. Storia dell'urbanistica dalle origini all'ellenismo [History of urbanism from origins to Hellenism.] Torino: Einaudi, 1968.

Díaz Recasens, Gonzalo. La tradición del patio en la arquitectura moderna Patio y Casa [The tradition of patio in the Modern Architecture.] DPA n 13 Departament de Projectes Arquitectònics. Barcelona: ETSAB UPC Edicions UPC, 1997.

Eisenman, Peter. The formal basis of Modern Architecture. Zurich: Lars Muller Publishers, 2006.

Espuelas, Fernando. Il Vuoto. Riflessioni sullo spazio in architettura [Void. Thougths on space in architecture.] Milano: Christian Marinotti Edizioni, 2004.

Frampton, Kennet. L'altro movimento moderno [The other Modern Movement.] Milano: Silvana Editoriale, 2015.

Gastón Girao, Cristina. Mies. El proyecto como revelación del lugar [Mies. The proyect as a relvelation of site.] Barcelona: Caja de Arquitectos, 2005. 
Janneret, Charles. Carta ai Genitori [Letter to his parents.] Library of Chaux-deFonds, 1907.

Kubler, George Alexander. The shape of time. Torino: Einaudi, 1976.

Le Corbusier, Janneret, Pierre. Oeuvre Compléte [Complete Work.] Zurich: Les Éditions D'architecture, 1964.

. Verso una Architettura [Towards an architecture.] Milano. Longanesi, 1984.

. Carnets. Voyage d'Orient Carnet $n^{\circ} 4$ [Notebooks. East travel.] Milano: Parigi, Electa, Fundación LC, 1987.

Martí Arís, Carlos. La casa binuclear según Marcel Breuer: el patio recobrado [The binuclear house following Marcel Breuer.] Barcelona, DPA: Documents de Projectes d'Arquitectura" No.13, 1997.

. Pabellón y patio, elementos de la arquitectura moderna [Patio and pavilion, elements of modern arquitectura.] Bogotá: DE-ARQ Revista de Arquitectura $n^{\circ}$ $2,2008$.

Neumayer, Fritz. Mies van der Rohe, la palabra sin artificio [Mies van der Rohe, words without artífice.] Madrid: El croquis ed, 1995.

Padovan, Richard. "El pabellón y el patio. Problemas culturales y espaciales de la arquitectura De Stijl" [Pavilion and patio. Cultural and spatial problems in De Stijl architecture.] In Espacio fluido versus espacio sistematico. Edited by Ricardo Guasch. Barcelona: ETSAV Ediciones UPC, 1995.

Prestinenza Puglisi, Luigi. Mies Saga. Personal web page. Prestinenza.it.

Revetlatt i Mira, Pere Joan. La casa pompeyana: Referencias al conjunto de casaspatio realizadas por L. Mies van der Rohe en la década 1930-40 [The Pompey house: connections with patio-house realized by L. Mies van der Rohe between 30 and 40.$]$ Doctoral Thesis. Barcelona, 1993.

Rowe, Collin and Fred Koetter. Collage City. Milano: Il Saggiatore, 1981.

Rykwert, Joseph. L'idea di città [The idea of town.] Torino: Einaudi, 1981.

Zevi, Bruno. Poetica dell'architettura Neoplastica [Poetic of neo-plastic architecture.] Torino: Einaudi, 1974. 